\title{
Peringkasan Teks Ekstraktif pada Dokumen Tunggal Menggunakan Metode Restricted Boltzmann Machine
}

\author{
Rully Widiastutik, Teknik Informatika AKNS, Lukman Zaman P.C.S.W., Teknologi Informasi iSTTS, \\ dan Joan Santoso, Teknologi Informasi iSTTS
}

\begin{abstract}
Abstrak-Penelitian yang dilakukan yaitu menghasilkan peringkasan teks ekstratif secara otomatis yang dapat membantu menghasilkan dokumen yang lebih pendek dari dokumen aslinya dengan cara mengambil kalimat penting dari dokumen sehingga pembaca dapat memahami isi dokumen dengan cepat tanpa membaca secara keseluruhan. Dataset yang digunakan sebanyak 30 dokumen tunggal teks berita berbahasa Indonesia yang diperoleh dari www.kompas.com pada kategori tekno. Dalam penelitian ini, digunakan sepuluh fitur yaitu posisi kalimat, panjang kalimat, data numerik, bobot kalimat, kesamaan antara kalimat dan centroid, bigram, tri-gram, kata benda yang tepat, kemiripan antar kalimat, huruf besar. Nilai fitur setiap kalimat dihitung. Nilai fitur yang dihasilkan ditingkatkan dengan menggunakan metode Restricted Boltzmann Machine (RBM) agar ringkasan yang dihasilkan lebih akurat. Untuk proses pengujian dalam penelitian ini menggunakan ROUGE-1. Hasil yang diperoleh dalam penelitian yaitu dengan menggunakan learning rate 0.06 menghasilkan recall, precision dan $f$-measure tertinggi yakni 0.744, 0.611 dan 0.669. Selain itu, semakin besar nilai compression rate yang digunakan maka hasil recall, precision dan $f$-measure yang dihasilkan akan semakin tinggi. Hasil peringkasan teks dengan menggunakan RBM memiliki nilai recall lebih tinggi $2.1 \%$, precision lebih tinggi $1.6 \%$ dan $f$ measure lebih tinggi $1.8 \%$ daripada hasil peringkasan teks tanpa RBM. Hal ini menunjukkan bahwa peringkasan teks dengan menggunakan RBM hasilnya lebih baik daripada peringkasan teks tanpa RBM.
\end{abstract}

Kata Kunci-Natural Language Processing, Peringkasan Teks, Restricted Boltzmann Machine, Teks Berita Berbahasa Indonesia.

\section{Pendahuluan}

$\mathrm{D}$ engan perkembangan teknologi internet menyebabkan jumlah data terus meningkat sehingga menyebabkan informasi yang tersedia semakin banyak. Salah satu informasi yang banyak ditemui di media online adalah artikel berita. Artikel berita merupakan salah satu dokumen berbasis teks. Dengan membaca artikel berita, pembaca dapat mengetahui informasi mengenai sesuatu yang sedang

Rully Widiastutik, Teknik Informatika, Akademi Komunitas Negeri Sumenep, Sumenep, Jawa Timur, Indonesia (e-mail: rullywidiastutik@gmail.com)

Lukman Zaman P.C.S.W, Teknologi Informasi, Institut Sains dan Teknologi Terpadu Surabaya, Surabaya, Jawa Timur, Indonesia (e-mail: 1z@stts.edu)

Joan Santoso, Teknologi Informasi, Institut Sains dan Teknolog Terpadu Surabaya, Surabaya, Jawa Timur, Indonesia (e-mail: joan@stts.edu) terjadi atau yang telah terjadi. Pembaca dapat mengalami kesulitan serta membutuhkan waktu yang lama dalam memahami isi dokumen apabila dokumen yang akan dibaca banyak dan panjang. Hal ini dapat menyebabkan berkurangnya minat seseorang dalam membaca. Namun apabila terdapat ringkasan dari sebuah teks atau dokumen akan membantu memahami isi dokumen dengan cepat tanpa harus membaca secara keseluruhan. Ringkasan adalah dokumen yang berisi informasi penting atau intisari dari dokumen asli yang dihasilkan dari satu atau lebih dokumen. Ringkasan dokumen yang dibuat secara manual akan membutuhkan waktu lama apabila dokumen yang akan diringkas banyak dan panjang. Oleh karena itu dalam penelitian ini diterapkan suatu sistem peringkasan teks secara otomatis yang dapat membantu dalam penyusunan kalimat mengenai intisari dari dokumen secara cepat[1].

Pada peringkasan teks terdapat dua pendekatan, yang pertama adalah pendekatan ekstraktif. Pendekatan ini menghasilkan ringkasan dengan cara mengambil kalimatkalimat penting dari dokumen asli dan menyusunnya menjadi dokumen yang lebih pendek. Yang kedua adalah pendekatan abstraktif. Pendekatan ini menghasilkan ringkasan dimana kalimat yang tersusun tidak ada dalam dokumen aslinya[1]. Terdapat dua kategori peringkasan teks yaitu peringkasan dokumen tunggal, dimana peringkasan diekstrak dari satu dokumen dan peringkasan multi dokumen, dimana peringkasan diekstrak dari beberapa dokumen yang saling berhubungan[2].

\section{Penelitian PEnUnJang}

Bab ini terdapat penjelasan dari beberapa jurnal ilmiah yang digunakan untuk perbandingan serta sebagai penunjang pada penelitian ini.

Penelitian yang dilakukan oleh Suputra (2017) yaitu menghasilkan ringkasan berdasarkan skor fitur-fitur penting dari kalimat pada sebuah dokumen. Fitur yang digunakan sebanyak tiga fitur, pertama adalah fitur keyword positif, kedua adalah fitur kemiripan antar kalimat, dan ketiga adalah fitur kemiripan kalimat dengan judul dokumen. Dari ketiga fitur tersebut yang memberikan pengaruh yang dominan adalah fitur kemiripan antar kalimat. Data yang digunakan pada saat percobaan yaitu artikel Bahasa Bali yang didapat dari berbagai sumber[3].

Penelitian yang dilakukan oleh Gotami, dkk (2018) yaitu menghasilkan ringkasan yang memiliki makna umum atau luas dengan menggunakan metode Latent Semantic Analysis 
(LSA). Digunakannya metode tersebut karena mampu mengekstrak struktur semantik atau makna yang tersembunyi pada sebuah kalimat. Untuk penyusunan urutan ringkasan pada tahap ekstraksi ringkasan menggunakan Cross method LSA. Data yang digunakan untuk pengujian yaitu 10 artikel berita kesehatan berbahasa Indonesia[4].

Penelitian yang dilakukan oleh Ambekar, dkk (2018) yaitu menghasilkan peringkasan teks menggunakan Restricted Boltzmann Machine (RBM). Terdapat lima fitur yang digunakan yaitu kesamaan judul, posisi kalimat, bobot term, panjang kalimat, skor kata benda yang tepat. Dataset yang digunakan merupakan data input yang tidak berlabel. RBM merupakan algoritma deep learning tanpa pengawasan. Dalam penelitiannya menjelaskan bahwa ringkasan dengan menggunakan algoritma deep learning tanpa pengawasan hasilnya lebih baik daripada ringkasan dengan menggunakan teknik pembelajaran terawasi karena tidak ada dataset pelatihan yang diperlukan. Sehingga metode tersebut lebih efisien[5].

Penelitian yang dilakukan oleh Elgamal, dkk (2019) yaitu menghasilkan sistem peringkasan teks otomatis pada teks arab. Dalam penelitiannya melakukan perbandingan antara algoritma deep learning menggunakan RBM dan algoritma clustering menggunakan LSA. Setelah dilakukan pengujian menunjukkan bahwa dengan algoritma deep learning menggunakan RBM memberikan hasil yang lebih baik dalam peringkasan teks arab[6].

Dari penelitian-penelitian tersebut maka dalam penelitian ini menghasilkan peringkasan teks ekstraktif secara otomatis pada dokumen tunggal menggunakan metode Restricted Boltzmann Machine (RBM). Peringkasan teks secara otomatis yang dihasilkan mampu menyusun dokumen dalam bentuk yang lebih pendek dari dokumen asli dengan cara mengambil kalimat penting dokumen asli tersebut. Terdapat sepuluh fitur yang digunakan dalam penelitian ini. Digunakan metode RBM karena dapat memberikan hasil yang lebih baik dalam peringkasan. Dalam penelitian ini, metode RBM digunakan untuk meningkatkan nilai fitur setiap kalimat sehingga ringkasan yang dihasilkan lebih akurat[7].

Gambar 1 merupakan arsitektur sistem dalam penelitian ini. Dokumen teks yang diinputkan dilakukan preprocessing untuk menghasilkan Term Index yang dapat digunakan pada tahap selanjutnya. Tahap selanjutnya adalah perhitungan nilai fitur setiap kalimat. Terdapat sepuluh fitur yang digunakan. Matriks fitur kalimat dibentuk. Nilai fitur kalimat yang telah dihitung ditingkatkan menggunakan metode RBM. Matriks fitur kalimat yang ditingkatkan dibentuk. Dilakukan perhitungan skor setiap kalimat pada dokumen. Kalimat yang termasuk dalam ringkasan yaitu kalimat yang memiliki urutan teratas berdasarkan skor sesuai compression rate yang ditentukan.

Gambar 2 merupakan sistem peringkasan teks ekstraktif pada dokumen artikel berita berbahasa Indonesia menggunakan metode Restricted Boltzmann Machine. Pada sistem tersebut user menginput dokumen berupa isi dari artikel berita. Kemudian sistem akan mengolah dokumen tersebut dan akan menampilkan hasil ringkasan sesuai panjang ringkasan yang ditentukan oleh user.

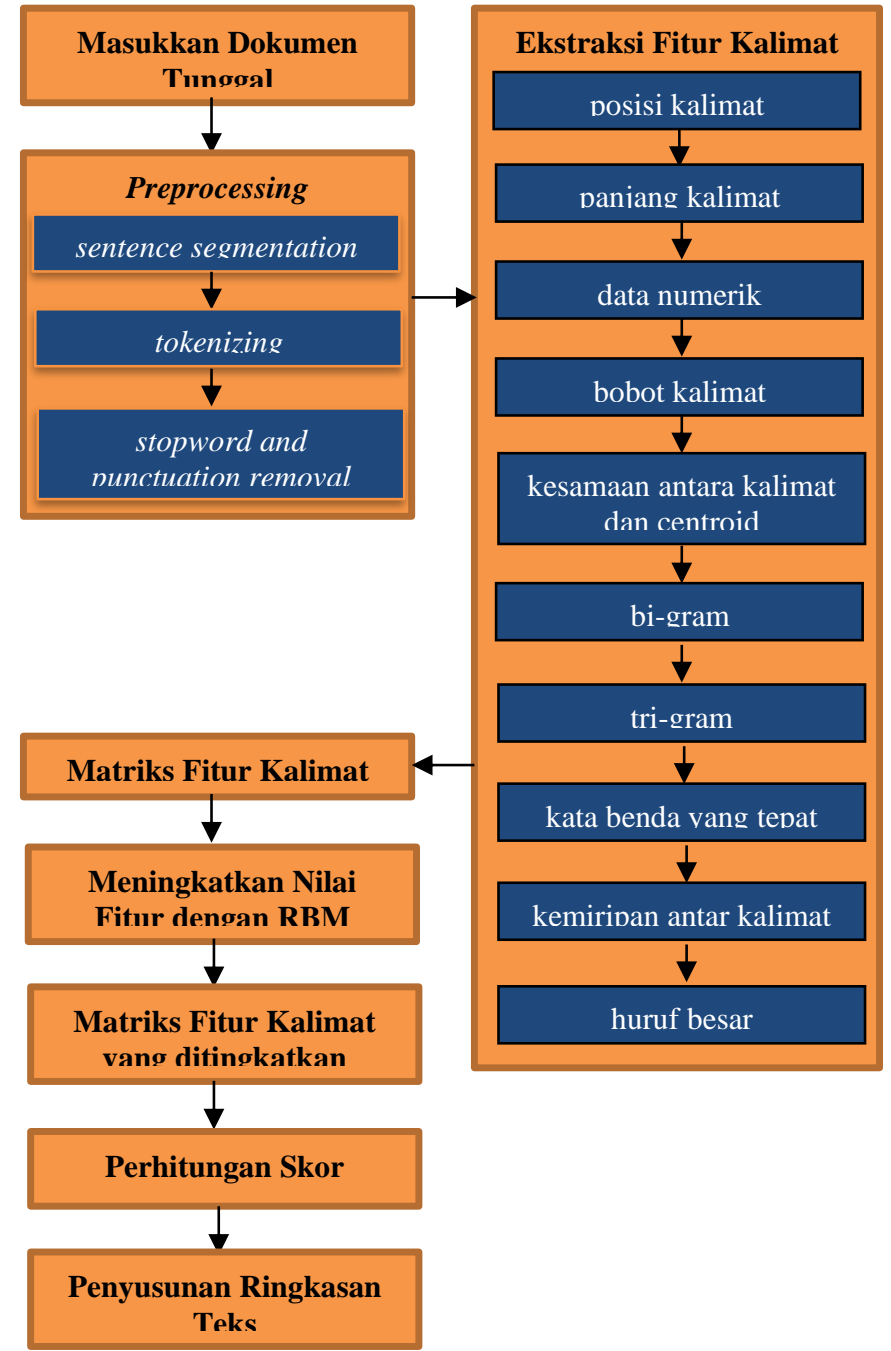

Gambar. 1. Arsitektur Sistem

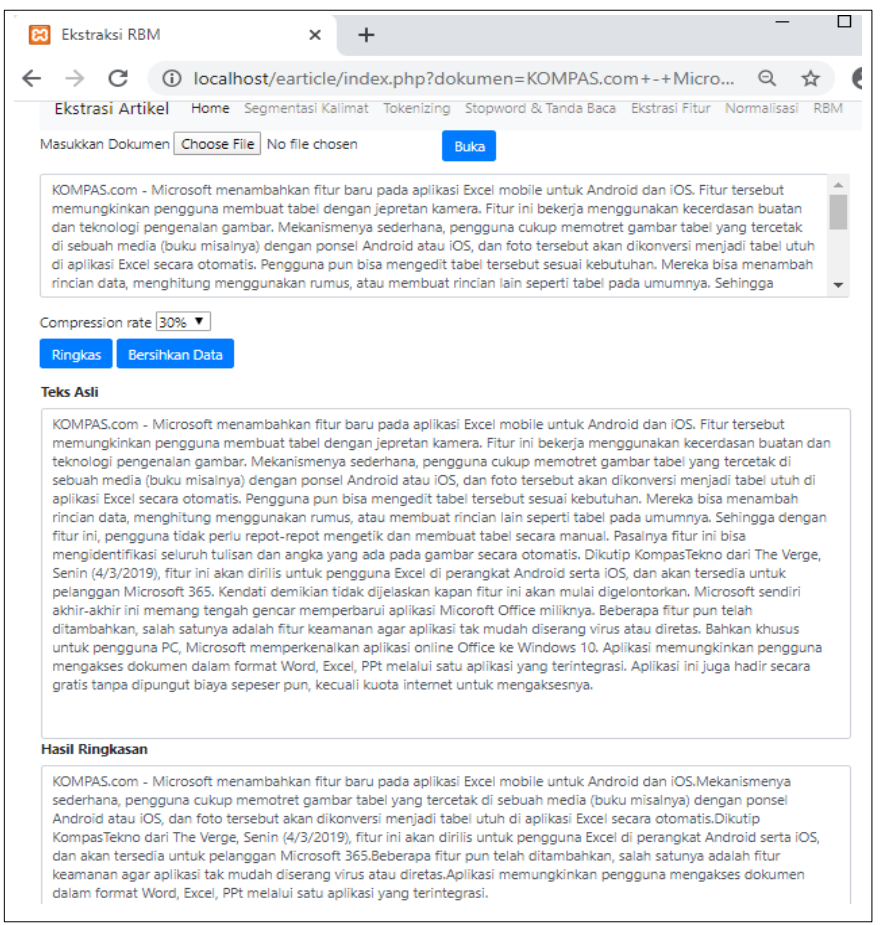

Gambar. 2. Sistem Peringkasan Dokumen Berita Menggunakan RBM 


\section{Metodologi}

\section{A. Preprocessing}

Tahap awal pada pemrosesan peringkasan teks yaitu preprocessing. Tujuan dilakukan preprocessing yaitu untuk menghasilkan Term Index dari dokumen teks sehingga dapat digunakan pada tahap selanjutnya[4]. Tahapan preprocessing yang digunakan pada penelitian ini meliputi tahapan sentence segmentation adalah proses pemisahan kalimat dengan pembatas karakter titik yang diikuti oleh karakter spasi menjadi komponen terpisah. Tahapan selanjutnya adalah tokenizing, pada tahapan ini kumpulan kalimat hasil segmentasi dilakukan proses pemisahan setiap kata untuk menjadi data tunggal. Yang terakhir adalah tahapan stopword and punctuation removal adalah proses penghapusan kata umum untuk mengurangi jumlah kemunculan kata yang kurang mempunyai arti seperti "dan", "atau", "adalah", "di", "lalu" dan lain-lain serta proses penghapusan tanda baca kecuali titik karena sebagai pembatas akhir kalimat.

\section{B. Ekstraksi Fitur kalimat}

Setelah dilakukan tahap preprocessing, tahap selanjutnya adalah perhitungan nilai fitur setiap kalimat. Pada penelitian ini digunakan sebanyak sepuluh fitur yaitu :

1. Fitur Posisi Kalimat

Posisi kalimat adalah letak kalimat dalam sebuah dokumen. Relevansi kalimat dapat diketahui berdasarkan posisinya dalam dokumen. Pada kalimat pertama atau terakhir dari dokumen selalu penting dan memiliki informasi maksimal. Sehingga untuk kalimat pertama atau terakhir, nilai fiturnya yaitu bernilai 1 . Sedangkan untuk kalimat lainnya dapat dihitung menggunakan persamaan (1)[8].

$$
P K=\frac{N-P}{N}
$$

Pada persamaan (1), variabel $P K$ adalah hasil perhitungan nilai fitur posisi kalimat untuk kalimat selain kalimat pertama atau terakhir. $N$ adalah total jumlah kalimat dalam dokumen dan $P$ adalah posisi kalimat dalam dokumen.

2. Fitur Panjang Kalimat

Kalimat yang sangat singkat tidak mengandung banyak informasi. Apabila jumlah kata dalam kalimat kurang dari 3 maka nilai fiturnya bernilai 0 . Sedangkan untuk yang lainnya dalam menentukan kalimat penting berdasarkan panjang kalimatnya dapat dihitung menggunakan persamaan (2)[7],[8].

$$
\text { Panjang_Kalimat }{ }_{i}=\frac{\text { jumlah } \text { kata } \text { pada kalimat } i}{\text { jumlah } \text { kata } \text { pada semua kalimat }}
$$

Pada persamaan (2), variabel Panjang_Kalimat ${ }_{i}$ adalah hasil perhitungan nilai fitur panjang kalimat pada kalimat ke- $i$. Untuk menghitung nilai fitur panjang kalimat pada kalimat ke- $i$ yaitu jumlah kata pada kalimat ke- $i$ dibagi dengan jumlah kata pada semua kalimat.

3. Fitur Data Numerik

Kalimat yang berisi data berupa bilangan juga dipertimbangkan dalam ringkasan karena data berupa bilangan dapat mempresentasikan suatu nilai penting pada dokumen. Fitur data numerik dapat dihitung menggunakan persamaan (3)[8].

Datanumerik $_{i}=\frac{\text { jumlah data numerik pada kalimat } i}{\text { jumlah } \text { kata pada kalimat } i}$

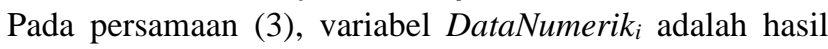

perhitungan nilai fitur data numerik pada kalimat ke-i. Untuk menghitung nilai fitur data numerik pada kalimat ke- $i$ yaitu jumlah data numerik pada kalimat ke- $i$ dibagi dengan jumlah kata pada kalimat ke- $i$. Data numerik yaitu data yang berupa bilangan.

4. Fitur Bobot Kalimat

Pada bobot kalimat menggunakan perhitungan tf-isf (term frequency-inverse sentence frequency). Tf-isf didapat dari frekuensi kemunculan kata pada kalimat beserta dengan jumlah dari frekuensi banyak kata yang muncul dalam sebuah dokumen. Frekuensi kemunculan kata pada kalimat dinyatakan dengan tf, jumlah kalimat yang terdapat dalam sebuah dokumen dinyatakan dengan $\mathrm{N}$, dan jumlah kalimat yang mengandung kata dinyatakan dengan n. Fitur bobot kalimat dapat dihitung menggunakan persamaan (4)[9].

$$
\text { Bobot_Kalimat }_{i}=t f_{i} x i s f_{i}=t f_{i} x\left(\log \frac{N}{n_{i}}\right)
$$

Pada persamaan (4), variabel Bobot_Kalimat ${ }_{i}$ adalah hasil perhitungan nilai fitur bobot kalimat pada kalimat ke- $i$. $t f_{i}$ adalah frekuensi kemunculan kata pada kalimat. $N$ adalah jumlah kalimat dalam satu dokumen. $n_{i}$ adalah jumlah kalimat dimana kata tersebut muncul.

\section{Fitur Kesamaan Antara Kalimat dan Centroid}

Kalimat yang fitur tf-isf maksimal digunakan sebagai kalimat centroid. Kesamaan antara kalimat dan centroid dapat dihitung menggunakan cosine similarity seperti pada persamaan (5)[8].

$$
\begin{aligned}
\operatorname{Cos}_{\text {sim }_{i}} & =\cos \left(\text { kalimat }_{\mathrm{i}}, \text { centroid }\right) \\
& =\frac{\text { kalimat }_{i} \cdot \text { centroid }}{\| \text { kalimat }_{i}\|\| \text { centroid } \|}
\end{aligned}
$$

Pada persamaan (5), variabel $\operatorname{Cos}_{\operatorname{Sim}_{i}}$ adalah hasil perhitungan nilai fitur kesamaan antara kalimat ke- $i$ dengan kalimat centroid. Variabel kalimat $_{i}$ adalah vektor kalimat ke$i$, yang akan dibandingkan kemiripannya. Variabel centroid adalah vektor kalimat centroid, yang akan dibandingkan kemiripannya. kalimat $_{i}$. centroid adalah dot product antara vektor kalimat ke- $i$ dan vektor kalimat centroid.

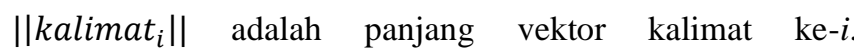
|lcentroid|| adalah panjang vektor kalimat centroid.

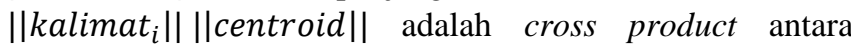

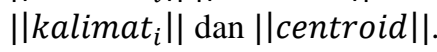

\section{Fitur Bi-gram}

Bi-gram adalah dua kata yang berdekatan pada setiap kalimat dalam dokumen. Nilai fitur Bi-gram dapat dihasilkan dengan cara menghitung jumlah total Bi-gram pada setiap kalimat[8].

7. Fitur Tri-gram

Tri-gram adalah tiga kata yang berdekatan pada setiap kalimat dalam dokumen. Nilai fitur Tri-gram dapat dihasilkan dengan cara menghitung jumlah total Tri-gram pada setiap kalimat[8].

\section{Fitur Kata Benda yang Tepat}

Kalimat memberi arti penting jika kalimat tersebut memiliki kata benda yang tepat. Kata benda yang tepat adalah kata yang digunakan untuk mengklasifikasikan orang, tempat, atau benda. Fitur kata benda yang tepat dapat dihitung menggunakan persamaan (6)[8].

$$
K B_{i}=\frac{\text { jumlah kata benda yang tepat pada kalimat } i}{\text { jumlah kata pada kalimat } i}
$$

Pada persamaan (6), variabel $K B_{i}$ adalah hasil perhitungan nilai fitur kata benda yang tepat pada kalimat ke-i. Untuk 
menghitung nilai fitur kata benda yang tepat pada kalimat ke- $i$ yaitu jumlah kata benda yang tepat pada kalimat ke- $i$ dibagi dengan jumlah kata pada kalimat ke- $i$.

9. Fitur Kemiripan Antar Kalimat

Kemiripan antar kalimat yaitu kata yang muncul dalam kalimat sama dengan kata yang muncul dalam kalimat lain. Kemiripan antar kalimat didapat dari jumlah jarak kedua kalimat dibagi jumlah maksimum jarak kedua kalimat. Fitur kemiripan antar kalimat dapat dihitung menggunakan persamaan (7)[9].

$$
K K=\frac{\sum \operatorname{Sim}(S i, S j)}{\operatorname{Max}\left(\sum \operatorname{Sim}(\operatorname{Si}, S j)\right)}
$$

Pada persamaan (7), variabel $K K$ adalah hasil perhitungan nilai fitur kemiripan antar kalimat. $\operatorname{Sim}\left(S_{i}, S_{j}\right)$ adalah kemiripan antar kalimat ke-i dan kalimat ke-j. $\sum \operatorname{Sim}(S i, S j)$ adalah jumlah kemiripan antar kalimat ke- $i$ dan kalimat ke-j. Dengan $S_{\mathrm{i}}, \mathrm{S}_{\mathrm{j}}$ diperoleh dari persamaan (8) jarak antar kalimat.

$$
S_{i}, S_{j}=\frac{\sum_{t=1}^{n} w_{t i} x w_{t j}}{\sqrt{\sum_{t=1}^{n} w_{t i}^{2}} x \sqrt{\sum_{t=1}^{n} w_{t j}^{2}}}
$$

Pada persamanan (8), $w_{t i}$ adalah bobot kata t pada kalimat $i$. $w_{t j}$ adalah bobot kata t pada kalimat $j . n$ adalah jumlah kata dalam kalimat. $\sum_{t=1}^{n} w_{t i} x w_{t j}$ adalah jumlah perhitungan skalar dari pembobotan kalimat. $\sqrt{\sum_{t=1}^{n} w_{t i}^{2}} x \sqrt{\sum_{t=1}^{n} w_{t j}^{2}}$ adalah jumlah perhitungan vektor dari pembobotan kalimat.

\section{Fitur Huruf Besar}

Kalimat yang berisi kata yang mengandung huruf besar mempunyai peluang dalam ringkasan karena kata yang mengandung huruf besar termasuk dalam kata yang dipentingkan pada dokumen. Fitur huruf besar dapat dihitung menggunakan persamaan (9)[10].

$$
H B=\frac{\text { banyak kata yang terdapat huruf besar }}{\text { banyak kata dalam kalimat }}
$$

Pada persamaan (9), variabel $H B$ adalah hasil perhitungan nilai fitur huruf besar pada setiap kalimat. Untuk menghitung nilai fitur huruf besar pada setiap kalimat yaitu banyak kata yang terdapat huruf besar dalam kalimat dibagi dengan banyak kata dalam kalimat.

\section{Matriks Fitur Kalimat}

Setelah setiap kalimat nilai fiturnya dihitung, selanjutnya matriks fitur kalimat dibentuk yang berupa matriks 2-d yang terdiri dari $\mathrm{S}=\left(\mathrm{s}_{1}, \mathrm{~s}_{2}, \mathrm{~s}_{3}, \ldots, \mathrm{s}_{\mathrm{N}}\right)$ adalah kalimat dalam dokumen dan $S_{i}=\left(f_{1}, f_{2}, f_{3}, f_{4}, f_{5}, f_{6}, f_{7}, f_{8}, f_{9}, f_{10}\right)$ adalah vektor fitur.

\section{Restricted Boltzmann Machine (RBM)}

Restricted Boltzmann Machine (RBM) merupakan model generatif probabilistik yang mampu secara otomatis mengekstrak fitur input data dengan menggunakan algoritma pembelajaran tanpa pengawasan. RBM adalah jaringan saraf yang bersifat stochastic. Jaringan saraf berarti memiliki unit neuron berupa aktivasi biner yang bergantung pada neuron-neuron yang saling terhubung. Sedangkan stochastic berarti aktivasi yang memiliki unsur probabilistik. RBM terdiri dari dua binary unit yaitu visible layer dan hidden layer serta unit bias. Visible layer merupakan state yang akan diobservasi dan hidden layer merupakan feature detectors. Masing-masing visible unit terhubung ke semua hidden unit yang diwakili oleh array bobot, sehingga masing-masing hidden unit juga terhubung ke semua visible unit dan unit bias terhubung ke semua visible unit dan semua hidden unit. Untuk memudahkan proses pembelajaran, jaringan dibatasi sehingga tidak ada visible unit terhubung ke visible unit lain dan hidden unit terhubung ke hidden unit lain.

Untuk melatih RBM, sampel dari training set yang digunakan sebagai input untuk RBM melalui neuron visible, dan kemudian jaringan sampel bolak balik antara neuron visible dan hidden. Tujuan dari pelatihan yaitu untuk pembelajaran koneksi bobot pada visible atau hidden dan bias aktivasi neuron sehingga RBM belajar untuk merekonstruksi data input selama fase dimana sampel neuron visible dari neuron hidden. Setiap proses sampling pada dasarnya berupa perkalian matriks antara sekumpulan sampel pelatihan dan matriks bobot, diikuti dengan fungsi aktivasi neuron yaitu fungsi sigmoid. Sampling antara lapisan hidden dan visible diikuti oleh modifikasi parameter (dikontrol oleh learning rate) dan diulang untuk setiap kelompok data dalam training set, dan untuk state sebanyak yang diperlukan untuk mencapai konvergensi[11].

Unit hidden diinisialisasi dan diperbaharui menggunakan persamaan (10), dimana $\mathrm{H}_{\mathrm{j}}$ dari setiap unit hidden $\mathrm{j}$ dengan nilai V (binari state unit visible) diatur satu dengan probabilitas :

$$
\mathrm{p}\left(\mathrm{H}_{j}=1 \mid V\right)=\sigma\left(b_{j}+\sum_{i} V_{i} W_{i j}\right)
$$

Dimana $\sigma(x)$ adalah fungsi sigmoid

$$
\sigma(x)=\frac{1}{1+\exp (-x)}
$$

Pada persamaan (10), $b_{j}$ adalah bias dari unit hidden. $V_{i}$ adalah binari state dari visible unit i. $W_{i j}$ adalah bobot antara unit visible dan unit hidden. $\mathrm{i}(\mathrm{i}=1,2,3, . ., \mathrm{n})$ untuk mewakili jumlah dari visible neuron. Sedangkan pada persamaan (11), $x$ merupakan hasil perhitungan dari $b_{j}+\sum_{i} V_{i} W_{i j}$.

Unit visible diinisialisasi dan diperbaharui menggunakan persamaan (12), dimana $\mathrm{V}_{\mathrm{i}}$ dari setiap unit visible $\mathrm{i}$ dengan nilai $\mathrm{H}$ (binari state unit hidden) diatur satu dengan probabilitas :

$$
\mathrm{p}\left(\mathrm{V}_{i}=1 \mid H\right)=\sigma\left(a_{i}+\sum_{j} H_{j} W_{i j}\right)
$$

Pada persamaan (12), $a_{i}$ adalah bias dari unit visible. $H_{j}$ adalah binari state dari hidden unit $\mathrm{j} . W_{i j}$ adalah bobot antara unit visible dan unit hidden. $\mathrm{j}(\mathrm{j}=1,2,3, . ., \mathrm{n})$ untuk mewakili jumlah dari hidden neuron. $\sigma$ adalah fungsi sigmoid yang dihitung dengan menggunaan persamaan (11).

Metode RBM digunakan dalam penelitian ini karena mampu meningkatkan nilai fitur sehingga ringkasan yang dihasilkan lebih akurat. Matriks fitur kalimat yang diperoleh dari proses sebelumnya dilakukan normalisasi dengan membagi setiap elemennya dengan elemen tertinggi, selanjutnya digunakan sebagai input RBM. Berikut adalah tahapan-tahapan menggunakan RBM[11] :

1. Inisialisasi data

a. Lakukan proses pencarian nilai bobot dan bias dengan nilai random yang kecil.

b. Tentukan Learning Rate dan maksimum Epoch yang akan digunakan.

c. Selama Epoch < MaksimumEpoch, lakukan langkah dibawah ini. 
d. Selama datasampel < maksimumdatasampel, lakukan langkah dibawah ini.

2. Fase Positif

Setelah tahap inisialisasi data, selanjutnya adalah tahap fase positif. Fase positif yaitu mengambil data dan sampel dari hidden unit.

a. Menghitung energi aktivasi, probabilitas dan state dari unit hidden dengan menggunakan persamaan (10).

b. Menghitung positif_assosiatif dengan menggunakan persamaan (13). Untuk menghitung positif assosiatif yaitu matriks data sampel dari visible neuron ditranspose dikali dengan probabilitas yang dihasilkan dari langkah 2(a).

$$
\text { Pos_Asso }=(\text { data })^{T} * P\left(H_{j}\right)
$$

Pada persamaan (13), (data) $)^{T}$ merupakan matriks data sampel dari visible neuron yang ditranspose. $P\left(H_{j}\right)$ merupakan probabilitas unit hidden yang dihasilkan dari langkah 2(a)

3. Fase Negatif

Tahap selanjutnya adalah fase negatif, yaitu merekonstruksi visible unit dan data sampel dari hidden unit.

a. Menghitung energi aktivasi dan probabilitas dari unit visible dengan menggunakan persamaan (12).

b. Melakukan langkah 2(a) untuk update hidden unit.

c. Menghitung negatif_assosiatif dengan menggunakan persamaan (14). Untuk menghitung negatif assosiatif yaitu matriks data (probabilitas dari unit visible yang diperoleh dari langkah 3(a)) yang ditranspose dikali dengan probabilitas dari unit hidden yang dihasilkan dari langkah 3(b).

$$
\text { Neg_Asso }=(\text { data })^{T} * P\left(H_{j}\right)
$$

Pada persamaan (14), (data) $)^{T}$ merupakan matriks data (probabilitas dari unit visible yang diperoleh dari langkah 3(a)) yang ditranspose. $P\left(H_{j}\right)$ merupakan probabilitas unit hidden yang dihasilkan dari langkah 3(b).

4. Update Bobot

Tahap selanjutnya adalah update bobot, dengan menggunakan persamaan (15).

$$
\begin{aligned}
& \mathrm{W}_{\mathrm{ij}}(\text { baru })=\mathrm{W}_{\mathrm{ij}}(\text { lama })+\Delta \mathrm{W}_{\mathrm{ij}} \\
& \Delta \mathrm{Wij}=\varepsilon\left(\text { Pos_Asso }-\mathrm{Neg} \_ \text {Asso }\right)
\end{aligned}
$$

Pada persamaan (15), $\mathrm{W}_{\mathrm{ij}}$ adalah bobot antara unit visible dan unit hidden. $\Delta \mathrm{W}_{\mathrm{ij}}$ adalah perubahan bobot. Untuk menghitung bobot yang baru yaitu bobot lama ditambah dengan perubahan bobot yang dihasilkan. Sedangkan pada persamaan (16), merupakan perhitungan perubahan bobot. $\varepsilon$ adalah learning rate. Perhitungan perubahan bobot $\Delta \mathrm{W}_{\mathrm{ij}}$ diperoleh dari learning rate dikali dengan selisih antara positif assosiatif dan negatif assosiatif.

5. Hitung Error

Untuk menghitung error menggunakan persamaan (17).

$$
\text { Error }=\frac{1}{2} \sum_{i=1}^{p}\left(O_{i}-t_{i}\right)^{2}
$$

Pada persamaan (17), Error dihitung dengan pengurangan $\mathrm{O}_{\mathrm{i}}$ merupakan data sampel dan $\mathrm{t}_{\mathrm{i}}$ merupakan visible probabilitas yang dihasilkan dari fase negatif pada langkah 3(a). $p$ adalah jumlah data.

Dalam penelitian ini, pada visible layer terdapat sepuluh neuron karena terdapat sepuluh fitur. Learning rate yang digunakan yaitu $0.01,0.03,0.06$ dan 0.09 serta pembatasan epoch sebanyak 50 epoch.

\section{E. Matriks Fitur Kalimat yang ditingkatkan}

Setelah setiap kalimat nilai fiturnya ditingkatkan dengan menggunakan metode RBM, maka diperoleh matriks fitur kalimat yang ditingkatkan.

\section{F. Perhitungan Skor Kalimat}

Setelah dihasilkan matriks fitur kalimat yang ditingkatkan, selanjutnya adalah menghitung skor setiap kalimat pada dokumen. Skor kalimat diperoleh dengan cara menghitung nilai total dari nilai fitur yang telah ditingkatkan pada setiap kalimat.

\section{G. Penyusunan Ringkasan Teks}

Kalimat diurut secara descending berdasarkan skor kalimat. Untuk menentukan kalimat dalam ringkasan yaitu kalimat yang memiliki urutan teratas sesuai compression rate yang ditentukan. Compression rate yang digunakan dalam penelitian ini yaitu 20\%, 30\% dan 40\%. Kalimat dalam ringkasan diurutkan sesuai dengan posisi asli dalam dokumen.

\section{DATASET ARTIKEl BERITA BERBAHASA INDONESIA}

Dataset yang digunakan dalam penelitian ini yaitu dokumen tunggal teks berita berbahasa Indonesia yang diperoleh dari www.kompas.com pada kategori tekno. Artikel berita yang digunakan sebanyak 30 artikel yang diambil dari postingan tanggal 1 Januari 2019 sampai 31 Maret 2019. Dataset yang digunakan dalam penelitian ini berupa isi dari artikel berita. Situs berita online kompas.com digunakan dalam penelitian ini karena kompas.com merupakan salah satu situs berita online di Indonesia yang sering dikunjungi[12]. Sedangkan kategori tekno yaitu mengulas tentang kabar berita terkini dunia IT meliputi gadget terbaru, games, apps, smartphone, review produk, internet, software dan hardware.

Dalam penelitian ini melibatkan seorang pakar yang dapat membantu dalam menentukan hasil ringkasan secara manual. Dimana nantinya hasil ringkasan manual tersebut digunakan sebagai pembanding pada saat melakukan pengujian. Hasil ringkasan manual dari pakar berupa data kuisioner yang terdiri dari dokumen-dokumen kalimat berita, selanjutnya pakar melakukan ceklist pada dokumen kalimat yang dianggap mengandung informasi penting yang mampu mewakili isi berita secara keseluruhan. Seorang pakar yang terlibat dalam penelitian ini yaitu guru Bahasa Indonesia. Guru Bahasa Indonesia dipilih karena dalam penelitian ini menggunakan dokumen teks berbahasa Indonesia.

\section{Pengujian}

Metode pengujian ringkasan yang digunakan dalam penelitian ini yaitu intrinsik. Metode intrinsik merupakan metode evaluasi dimana kualitas ringkasan diukur berdasarkan hasil ringkasan yang dihasilkan. Dalam evaluasinya, dilakukan perbandingan antara hasil ringkasan sistem dengan hasil ringkasan manual yang dibuat oleh pakar. 
Recall Oriented Understudy for Gisting Evaluation (ROUGE) adalah proses pengujian dengan menghitung jumlah $n$-gram yang sama antara ringkasan sistem dengan ringkasan manual. Dalam penelitian ini menggunakan ROUGE-1 karena memiliki tes signifikan recall yang tinggi. ROUGE-1 yaitu menghitung jumlah unigram kata yang sama antara ringkasan sistem dengan ringkasan manual. Parameter untuk evaluasi kenerja adalah Recall, Precision dan F-Measure dengan menggunakan persamaan 18, 19, dan 20[13].

ROUGE-N Recall $=\frac{\text { Common } N-\text { grams }(\text { Peer }, \text { Reference })}{N-\text { grams }(\text { Reference })}$

ROUGE-N Precision $=\frac{\text { Common } N-\text { grams }(\text { Peer }, \text { Reference })}{N-\text { grams }(\text { Peer })}(19)$

ROUGE-N F-Measure $=\frac{2 * \text { Precision } * \text { Recall }}{\text { Precision }+ \text { Recall }}$

Pada persamaan (18), persamaan (19), dan persamaan (20) terdapat tiga komponen penting yaitu Common $\mathrm{N}$ grams(Peer,Reference) adalah jumlah n-gram dalam ringkasan sistem dan ringkasan manual. $N$-grams(reference) adalah jumlah $n$-gram dalam ringkasan manual. $N$ grams(peer) adalah jumlah $n$-gram dalam ringkasan sistem.

Proses pengujian yang dilakukan dalam penelitian ini yaitu pengujian berdasarkan learning rate, pengujian berdasarkan compression rate dan melakukan perbandingan antara hasil ringkasan menggunakan RBM dan tanpa RBM.

\section{A. Pengujian berdasarkan Learning Rate}

TABEL I

HASIL PENGUJIAN BERDASARKAN LEARNING RATE

\begin{tabular}{|c|c|c|c|}
\hline $\begin{array}{c}\text { Learning Rate } \\
(\boldsymbol{\varepsilon})\end{array}$ & Recall & Precision & F-Measure \\
\hline 0.01 & 0.728 & 0.604 & 0.657 \\
\hline 0.03 & 0.737 & 0.610 & 0.664 \\
\hline 0.06 & 0.744 & 0.611 & 0.669 \\
\hline 0.09 & 0.736 & 0.603 & 0.660 \\
\hline
\end{tabular}

Terdapat empat learning rate yang digunakan dalam pengujian ini yaitu $0.01,0.03,0.06$ dan 0.09. Dalam pengujian digunakan 30 dokumen artikel berita berbahasa Indonesia dengan compression rate $40 \%$. Pembatasan epoch yang digunakan sebanyak 50 epoch. Pengujian ini dilakukan untuk mengetahui hasil recall, precision dan f-measure berdasarkan learning rate yang diuji. Dari hasil pengujian, tampak bahwa learning rate dengan 0.06 menghasilkan recall, precision dan $f$-measure tertinggi seperti yang terlihat pada tabel I.

\section{B. Pengujian berdasarkan Compression Rate}

Dalam pengujian ini, compression rate yang digunakan yaitu 20\%, 30\% dan $40 \%$ dari setiap data dokumen. Sebanyak 30 dokumen artikel berita berbahasa Indonesia yang digunakan. Pengujian ini dilakukan untuk mengetahui hasil recall, precision dan f-measure berdasarkan compression rate yang diuji. Pada gambar 3 tampak bahwa hasil recall, precision dan $f$-measure tertinggi pada saat pengujian dengan menggunakan compression rate $40 \%$.

C. Pengujian dengan Membandingkan antara Hasil Peringkasan menggunakan RBM dan tanpa RBM

Pengujian ini dilakukan untuk mengetahui perbandingan antara hasil peringkasan dengan menggunakan RBM dan hasil peringkasan tanpa RBM. Dari hasil pengujian, tampak bahwa terdapat perbedaan hasil rata-rata recall, precision dan f-measure pada peringkasan menggunakan RBM dengan peringkasan tanpa RBM. Nilai rata-rata recall, precision dan $f$-measure pada peringkasan menggunakan RBM lebih tinggi daripada nilai rata-rata recall, precision dan $f$-measure pada peringkasan tanpa RBM seperti yang terlihat pada tabel II.

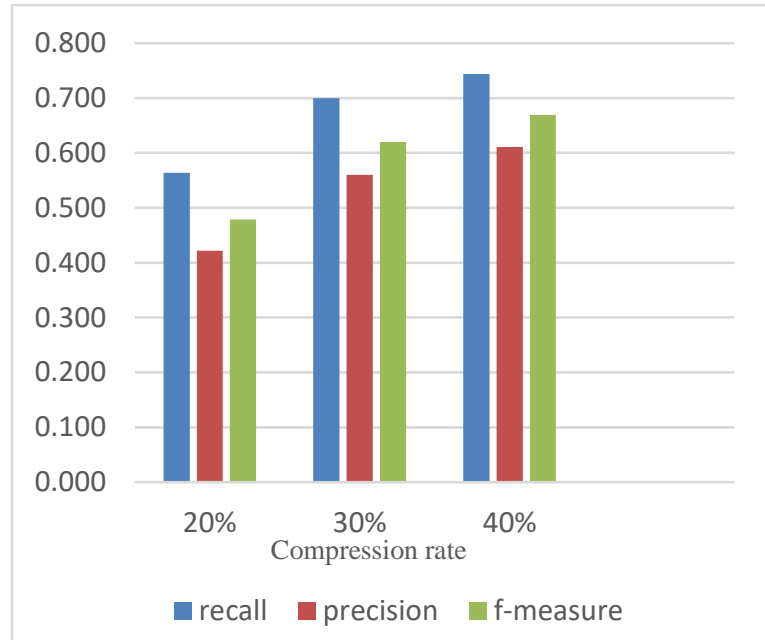

Gambar. 3. Grafik Hasil Pengujian berdasarkan Compression Rate

TABEL II

HASIL PENGUJIAN BERDASARKAN PERBANDINGAN ANTARA MENGGUNAKAN RBM DAN TANPA RBM

\begin{tabular}{|c|c|c|c|c|c|c|}
\hline \multirow{2}{*}{ Artikel } & \multicolumn{3}{|c|}{ Dengan RBM } & \multicolumn{3}{|c|}{ Tanpa RBM } \\
\hline & $\mathbf{R}$ & $\mathbf{P}$ & $\mathbf{F}$ & $\mathbf{R}$ & $\mathbf{P}$ & $\mathbf{F}$ \\
\hline 1 & 0.4953 & 0.3926 & 0.4380 & 0.4953 & 0.3926 & 0.4380 \\
\hline 2 & 0.6879 & 0.6136 & 0.6486 & 0.6879 & 0.6136 & 0.6486 \\
\hline 3 & 0.5773 & 0.4786 & 0.5234 & 0.5773 & 0.4786 & 0.5234 \\
\hline 4 & 0.4588 & 0.4382 & 0.4483 & 0.4588 & 0.4382 & 0.4483 \\
\hline 5 & 0.8107 & 0.6009 & 0.6902 & 0.6627 & 0.5068 & 0.5744 \\
\hline 6 & 0.8065 & 0.7813 & 0.7937 & 0.8065 & 0.7813 & 0.7937 \\
\hline 7 & 0.9130 & 0.6087 & 0.7304 & 0.9130 & 0.6087 & 0.7304 \\
\hline 8 & 0.7822 & 0.6870 & 0.7315 & 0.7822 & 0.6870 & 0.7315 \\
\hline 9 & 1.0000 & 0.7248 & 0.8404 & 1.0000 & 0.7248 & 0.8404 \\
\hline 10 & 0.8049 & 0.5593 & 0.6600 & 0.8049 & 0.5593 & 0.6600 \\
\hline 11 & 0.7216 & 0.5983 & 0.6542 & 0.7216 & 0.5983 & 0.6542 \\
\hline 12 & 0.5833 & 0.3203 & 0.4135 & 0.5476 & 0.3108 & 0.3966 \\
\hline 13 & 0.5446 & 0.4766 & 0.5083 & 0.5446 & 0.4766 & 0.5083 \\
\hline 14 & 0.6835 & 0.5243 & 0.5934 & 0.6835 & 0.5243 & 0.5934 \\
\hline 15 & 0.6458 & 0.4189 & 0.5082 & 0.6563 & 0.4286 & 0.5185 \\
\hline 16 & 0.6364 & 0.5469 & 0.5882 & 0.6364 & 0.5469 & 0.5882 \\
\hline 17 & 0.9070 & 0.5821 & 0.7091 & 0.9070 & 0.5821 & 0.7091 \\
\hline 18 & 0.5960 & 0.5728 & 0.5842 & 0.5960 & 0.5728 & 0.5842 \\
\hline 19 & 0.7092 & 0.5917 & 0.6452 & 0.7092 & 0.5917 & 0.6452 \\
\hline 20 & 0.6463 & 0.5521 & 0.5955 & 0.5244 & 0.4624 & 0.4914 \\
\hline 21 & 0.6981 & 0.5606 & 0.6218 & 0.6981 & 0.5606 & 0.6218 \\
\hline 22 & 0.8169 & 0.7073 & 0.7582 & 0.8169 & 0.7073 & 0.7582 \\
\hline 23 & 0.8721 & 0.6466 & 0.7426 & 0.8721 & 0.6466 & 0.7426 \\
\hline 24 & 0.8542 & 0.7736 & 0.8119 & 0.7292 & 0.6863 & 0.7071 \\
\hline 25 & 0.7015 & 0.4845 & 0.5732 & 0.6418 & 0.4526 & 0.5309 \\
\hline 26 & 0.5765 & 0.5385 & 0.5568 & 0.5765 & 0.5385 & 0.5568 \\
\hline 27 & 0.5301 & 0.3385 & 0.4131 & 0.5301 & 0.3385 & 0.4131 \\
\hline 28 & 0.6742 & 0.6122 & 0.6417 & 0.5393 & 0.4528 & 0.4923 \\
\hline 29 & 0.5783 & 0.4948 & 0.5333 & 0.5783 & 0.4948 & 0.5333 \\
\hline 30 & 0.7000 & 0.5698 & 0.6282 & 0.6857 & 0.5714 & 0.6234 \\
\hline Rerata & 0.700 & 0.560 & 0.620 & 0.679 & 0.544 & 0.602 \\
\hline
\end{tabular}




\section{KESIMPULAN}

Dalam melakukan peringkasan teks ekstraktif secara otomatis dengan menggunakan metode Restricted Boltzmann Machine (RBM), salah satu yang perlu diperhatikan yaitu penentuan learning rate yang akan digunakan agar ringkasan yang dihasilkan baik. Berdasarkan pengujian yang dilakukan dalam penelitian ini, dengan menggunakan learning rate 0.06 menghasilkan recall, precision dan f-measure tertinggi yakni $0.744,0.611$ dan 0.669 .

Compression rate digunakan dalam peringkasan untuk menentukan panjang ringkasan yang dihasilkan. Berdasarkan pengujian yang dilakukan, semakin besar nilai compression rate yang digunakan maka hasil recall, precision dan $f$-measure yang dihasilkan akan semakin tinggi.

Pada peringkasan teks tanpa RBM diperoleh nilai ratarata recall 0.679 , precision 0.544 dan $f$-measure 0.602 . Sedangkan pada peringkasan teks menggunakan metode RBM diperoleh nilai rata-rata recall 0.700 , precision 0.560 dan f-measure 0.620. Peringkasan teks dengan menggunakan metode RBM menghasilkan nilai rata-rata recall, precision dan $f$-measure lebih tinggi daripada peringkasan teks tanpa menggunakan RBM, walaupun perbedaan hasil yang diperoleh tidak terlalu jauh. Peringkasan teks menggunakan metode RBM memiliki nilai recall lebih tinggi $2.1 \%$, precision lebih tinggi $1.6 \%$ dan $f$ measure lebih tinggi $1.8 \%$ daripada peringkasan teks tanpa RBM. Hal ini menunjukkan bahwa peringkasan teks dengan menggunakan RBM hasilnya lebih baik daripada peringkasan teks tanpa RBM.

Pada metode RBM yang digunakan dalam penelitian ini masih perlu dilakukan improvisasi dalam penentuan nilai bobot dan bias yang akan digunakan agar ringkasan yang dihasilkan lebih baik lagi. Untuk penelitian selanjutnya dapat menambahkan fitur selain yang ada pada penelitian ini serta metode ini dapat dikombinasikan dengan metode lain untuk meningkatkan hasil peringkasan.

\section{DAFTAR PUSTAKA}

[1] J. S. Saputra, M. Fachrurrozi, Yunita, "Peringkasan Teks Berita Berbahasa Indonesia Menggunakan Metode Latent Semantic Analysis (LSA) dan Teknik Steinberger \& Jezek," in Prosiding Annual Research Seminar Computer Science and ICT, 2017.

[2] S. Irawan, Hermawan, Samsuryadi, "Studi Awal Peringkasan Dokumen Bahasa Indonesia Menggunakan Metode Latent Semantik Analysis dan Maximum Marginal Relevance," in Prosiding Annual Research Seminar, 6 Desember 2016.

[3] I P. G. H. Suputra. (2017, April). Peringkasan Teks Otomatis Untuk Dokumen Bahasa Bali Berbasis Metode Ektraktif. Jurnal Ilmu Komputer. $\quad \mathrm{X}(1), \quad$ pp. 33-38. Available: https://ojs.unud.ac.id/index.php/jik/article/view/39775/24171

[4] N. S. W. Gotami, Indriati, R. K. Dewi. (2018, September). Peringkasan Teks Otomatis Secara Ekstraktif Pada Artikel Berita Kesehatan Berbahasa Indonesia Dengan Menggunakan Metode Latent Semantic Analysis. Jurnal Pengembangan Teknologi Informasi dan Ilmu Komputer. 2(9), pp. 2821-2828. Available: http://jptiik.ub.ac.id/index.php/j-ptiik/article/view/2430/905

[5] A. Ambekar, K. Shah, M. Agrawal, S. Pawar, A. Shaikh. (2018, June). Text Summarization Using Restricted Boltzmann Machine: Unsupervised Deep Learning Approach. IJSART. 4(6), pp. 103-107. Available: http://ijsart.com/Content/PDFDocuments/IJSARTV4I623858.pdf

[6] M. Elgamal, Prof. Dr S. Hamada, Prof. Dr R. Aboelezz and Dr M. Abou-Kreisha. (2019, August). Better Results in Automatic Arabic
Text Summarization System Using Deep Learning based RBM than by Using Clustering Algorithm based LSA. International Journal of Scientific \& Engineering Research. 10(8), pp. 781-786. Available: https://www.ijser.org/researchpaper/Better-Results-in-AutomaticArabic-Text-Summarization-System-Using-Deep-Learning-basedRBM-than-by-Using-Clustering-Algorithm-based-LSA.pdf

[7] S. P. Singh, A. Kumar, A. Mangal, S. Singhal. (2016). Bilingual Automatic Text Summarization Using Unsupervised Deep learning. IEEE International Conference on Electrical, Electronics, and Optimization Techniques (ICEEOT). pp. 1195-1200. Available: https://ieexplore.ieee.org/document/7754874

[8] N. S. Shirwandkar, Dr. S. Kulkarni. (2018). Extractive Text Summarization using Deep Learning. IEEE Fourth International Conference on Computing Communication Control and Automation (ICCUBEA). Available: https://ieeexplore.ieee.org/document/8697465

[9] N. I. Widiastuti, W. K. Afnan. (2017). Fuzzy Logic dan Lexical Chains untuk Peringkasan Teks Otomatis. Jurnal Sistem Komputer. 7(1), pp. 5-12. Available: https://docplayer.info/91149501-Fuzzylogic-dan-lexical-chains-untuk-peringkasan-teks-otomatis.html

[10] A. Ridok, T. C. Romadhona, "Peringkasan Dokumen Otomatis Menggunakan Metode Fuzzy Model Sistem Inferensi Mamdani," in Seminar Nasional Teknologi Informasi dan Multimedia, Yogyakarta, 19 Januari 2013, pp. 19-24.

[11] Susilawati, "Algoritma Restricted Boltzmann Machines (RBM) untuk Pengenalan Tulisan Tangan Angka," in Seminar Nasional Teknologi Informatika, "The Future of Computer Vision", 2017, pp. 140-148.

[12] D. Branding (2019) "Ini Dia 7 Situs Berita Online di Indonesia yang Sering di Kunjungi," [Online]. https://www.nataconnexindo.com/blog/ini-dia-7-situs-berita-onlinedi-indonesia-yang-sering-di-kunjungi, tanggal akses: 21-Mei-2020.

[13] J. Yadav, Dr. Y. K. Meena. (2016, Sept). Use of Fuzzy Logic and WordNet for Improving Performance of Extractive Automatic Text Sumarization. IEEE Intl. Conference on Advances in Computing, Communications and Informatics (ICACCI). pp. 2071-2077. Available: https://ieeexplore.ieee.org/document/7732356

Rully Widiastutik lahir di Sumenep, Jawa Timur, Indonesia, pada tahun 1988. Menyelesaikan studi S1 di program studi Teknik Informatika Universitas Trunojoyo Madura pada tahun 2010, dan berkarir sebagai dosen di program studi Teknik Informatika Akademi Komunitas Negeri Sumenep. Minat penelitiannya adalah bidang text mining.

Lukman Zaman P. C. S. W berkarir sebagai dosen di program studi Teknologi Informasi Institut Sains dan Teknologi Terpadu Surabaya.

Joan Santoso lahir di Surabaya, Jawa Timur, Indonesia. Telah menyelesaikan pendidikan S1 pada tahun 2011 dan S2 pada tahun 2013 dari Sekolah Tinggi Teknik Surabaya. Minat penelitiannya ialah computational linguistic, information extraction, machine learning, dan big data processing. 